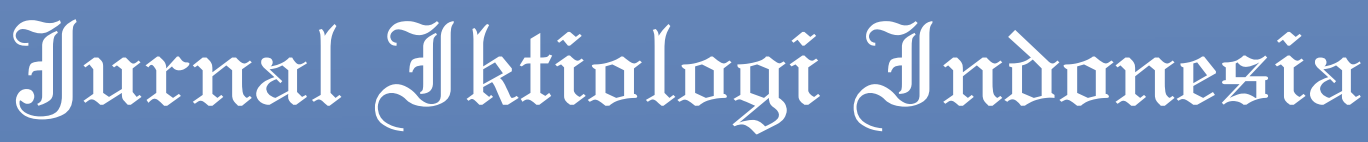

(Indonesian Journal of Ichthyology)

Volume 20 Nomor 1 Februari 2020

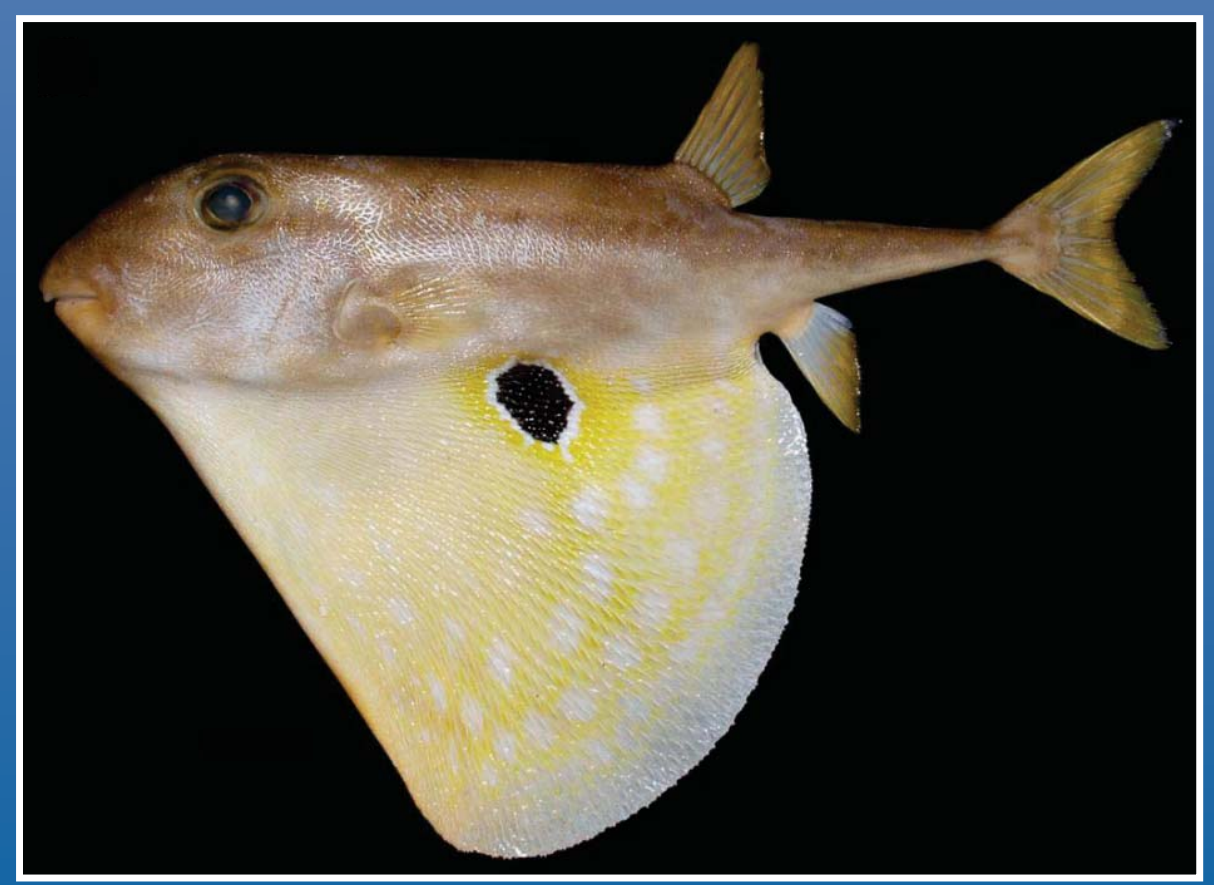

Diterbitkan oleh:

Masyarakat Iktiologi Indonesia (The Indonesian Ichthyological Society)

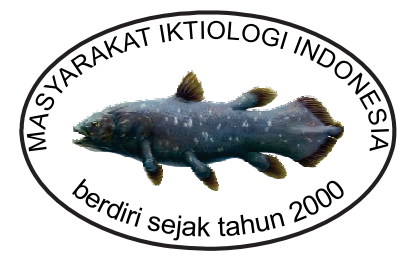




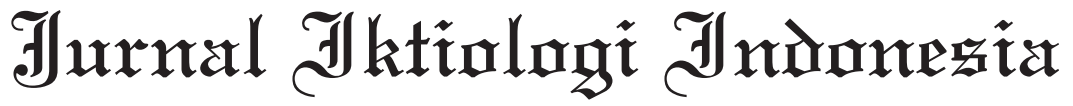

\author{
p ISSN 1693-0339 \\ e ISSN 2579-8634
}

Terakreditasi berdasarkan Keputusan Direktur Jenderal Penguatan Riset dan Pengembangan, Kementerian Riset, Teknologi, dan Pendidikan Tinggi No. 10/E/KPT/2019 tentang Peringkat Akreditasi Jurnal IImiah Periode II Tahun 2019 tertanggal 4 April 2019

Peringkat 2, berlaku lima tahun mulai dari Volume 19, Nomor 1, tahun 2019

Volume 20 Nomor 1 Februari 2020

\section{Dewan Penyunting}

Ketua

Anggota

\author{
: M. Fadjar Rahardjo \\ : Agus Nuryanto \\ Achmad Zahid \\ Angela Mariana Lusiastuti \\ Charles P.H. Simanjuntak \\ Djumanto \\ Endi Setiadi Kartamihardja \\ Haryono \\ Kadarusman \\ Lenny S. Syafei \\ Lies Emmawati Hadie \\ Sharifuddin bin Andy Omar \\ Teguh Peristiwady
}

\section{Alamat Dewan Penyunting:}

Gd. Widyasatwaloka, Bidang Zoologi, Pusat Penelitian Biologi-LIPI

Jln. Raya Jakarta-Bogor Km 46, Cibinong 16911

Laman: jurnal-iktiologi.org

Laman: www.iktiologi-indonesia.org

Surel: iktiologi_indonesia@yahoo.co.id

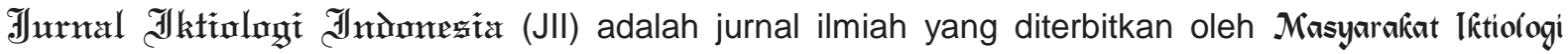
Indonesia (MII) tiga kali setahun pada bulan Februari, Juni, dan Oktober. JII menyajikan artikel lengkap hasil penelitian yang berkenaan dengan segala aspek kehidupan ikan (Pisces) di perairan tawar, payau, dan laut. Aspek yang dicakup antara lain biologi, fisiologi, taksonomi dan sistematika, genetika, dan ekologi, serta terapannya dalam bidang penangkapan, akuakultur, pengelolaan perikanan, dan konservasi.

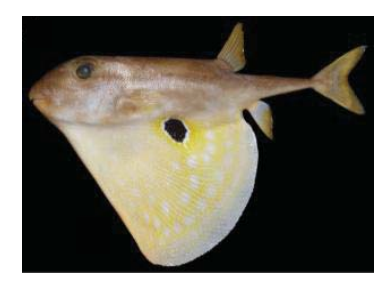

Ikan buntal laut dalam langka Triodon macropterus Lesson (1831) (Foto: Kunto Wibowo)

Percetakan: CV. Rajawali Corporation 


\section{Prakata}

Para penulis dan pembaca yang budiman,

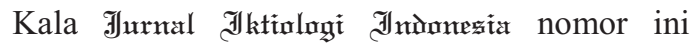
sampai di tangan anda, jauh terlambat daripada yang seharusnya yaitu Februari. Alasannya tidak lain dan tidak bukan adalah kegiatan semua terhambat oleh covid 19. Draft sebenarnya sudah siap untuk dicetak pada akhir Februari 2020. Marilah kita masuki tahun 2020 ini dengan rasa prihatin.

Nomor ini dibuka dengan tulisan tentang kandungan mikroplastik yang terdapat pada empat jenis ikan ekonomis penting di perairan selat Bali yang ditulis oleh Yona et al. Masih terkait dengan Selat Bali, Oktaviyani et al. melaporkan tentang komposisi spesies dan distribusi ikan hiu dan pari yang tertangkap di selat ini. Wibowo et al. menyampaikan catatan distribusi ikan buntal laut dalam langka Triodon macropterus dari Laut Maluku dan Laut Sawu

Dalam nomor ini terdapat tiga tulisan yang terkait dengan ikan budi daya. Yang pertama Syahril et al. menuliskan tentang tetraploidisasi kejut suhu dingin pada ikan patin siam. Yang kedua, Teduh et al. menguraikan tentang produksi albino slayer melalui kombinasi persilangan pada ikan hias brushmouth. Yang ketiga, Hirnawati et al. mengevaluasi kualitas warna dan aktivitas antioksidan yuwana ikan botia dengan penambahan astaksantin dalam pakan.

Dua tulisan terakhir mengutarakan tentang reproduksi ikan ekor pedang di Danau Tamblingan, Bali oleh Parawangsa et al. ; dan tentang pengangkutan sistem tertutup, pemeliharaan, dan pengamatan telur Oryzias javanicus yang ditulis oleh Herjayanto et al.

Selamat membaca delapan artikel yang dimuat dalam jurnal kita nomor ini. Semoga mendapat manfaat. 